\title{
THE MUI'S VIEW ON AHMADIYAH AND THE DISPUTE SURROUNDING IT
}

\author{
Lilik Rofiqoh \\ A former student of Universiteit Leiden \\ Mobile Phone: \\ Lilik_hoqi4@yaboo.com
}

\begin{abstract}
The MUI, an ulama organization founded by the government in 1975, was engineered to be the national authority on Islam. This organization functions as a forum for the ulama to discuss problems related to 'the duties of ulama'. Therefore, the organization issues religious decrees in the form of fatwa and recommendation to respond cases in the society including the Abmadiyah case. Thus, this article aims at describing the aforementioned fatwa and recommendation on the Ahmadiyah and the debate around them.

MUI, sebuah organisasi ulama yang dibentuk pemerintah pada tahun 1975, ditujukan sebagai pemegang otoritas nasional dalam Islam di Indonesia. Organisasi ini berfungsi sebagai forum bagi para ulama untuk mendiskusikan berbagai masalah terkait dengan tugas ulama. Oleh karena itu, organisasi ini mengeluarkan keputusan-keputusan dalam bentuk fatwa- fatwa dan rekoomendasi untuk merespon berbagai macam masalah dalam masyarakat termasuk. kasus Ahmadiyah. Tulisan ini bermaksud menjelaskan fatwa-fatwa dan rekomendasi yang telah dikeluarkan MUI tentang Ahmadiyah dan perdebatan seputar fatwa tersebut.
\end{abstract}

Keywords: MUI, Fatwa, Recommendation, Ahmadiyah.

\section{Introduction}

The longest recorded issue on religious heresy is on the Ahmadiyah case. This denomination received the denunciation from the society, organizations and institutions. The denunciation was firstly emerged in 1926 when the indigenous Muslims in Sumatra noticed that the doctrines brought by the preacher of Ahmadiyah background were different from theirs, the mainstream Sunni Islam. Additionally, in 1929 the Muhammadiyah issued a resolution stating that anyone believing in the existence of a prophet after the Prophet Muhammad was considered an "unbeliever." Though the Ministry of Justice acknowledged Ahmadiyah as a corporation in 1953, the Indonesian Muslims continuously denied its existence. In 1965, the provincial MUI of West Sumatra issued a fatwa on Ahmadiyya Qadian as a deviant denomination. Another rejection came in 1973 from the North Sumatran government which refused to issue a license for building an Ahmadiyah Mosque. In the same year, the District Military Command of South Sumatra arrested two Ahmadiyah preachers. In 1976 the District Attorney of Subang West Java issued a decree on the banning on the Ahmadiyah and a recommendation to the regency MUI in Subang to retrain the followers of the Ahmadiyah Qadian. The last decree was issued by the General 
Attorney three days before the MUI issued its first fatwa on the Ahmadiyah doctrine on June $1^{\text {st }}, 1980$. In later development, the MUI also established a recommendation in 1984 and another fatwa in 2005. The later fatwa encouraged many intellectuals to speak about Islam and religious freedom.

These phenomena encouraged me to explore the fatwas, the recommendation and the case surrounding their issuances more comprehensively. In this article I would like to find the answers of how is the MUI's view on the Ahmadiyah case? In finding the answer for the question, I describe the background behind issuing these religious decrees and their contents.

\section{Analyses on the Three Religious Decrees Issued by the MUI on Ahmadiyah}

The MUI has issued two fatwas and one recommendation on the Ahmadiyah teachings. Each of them is discussed in details together with the other decrees issued preceding and following their issuance.

\section{Fatwa on the Banning of the Ahmadiyah Qadian Doctrine in 1980}

Before the MUI issued the first fatwa on the Ahmadiyah doctrine in 1980, there were two fatwas issued by the Muslim World League ${ }^{1}$ in 1974 and the Malaysian government in 1975 on the banning of the Ahmadiyah doctrines. This fact raised at least two questions. Why did the MUI issue the fatwa on the Ahmadiyah doctrine five years

\footnotetext{
${ }^{1}$ The Muslims World League is an Islamic nongovernmental organization based in Saudi Arabia and controlled and Funded by the Saudi government. It was founded in 1962 by the representatives of 22 countries. http://www.discoverthenetworks.org/groupProfile. asp?grpid=7347. I cannot get the information on when Indonesia joined this organization. But in 1975 Indonesia had its representatives in this organization. Hamka himself was appointed by the Minister of Religious Affairs at the time to attend the Mosque congress held by the Muslims World League in September 1975. See Prof. Dr. Hamka, "Pidato Ketua Umum Majelis Ulama Indonesia Empat Tahun," Mimbar Ulama 1984, pp. 49-50
}

after its establishment? And why did the MUI ignore the decree of the Muslim World League while Indonesia was one of its active members?

In fact, in its first year of establishment the MUI was busy with administration matters such as working schedule, basic policies, and fund. ${ }^{2}$ Besides, the MUI made an effort to introduce its existence through the Islamic Brotherhood Commission which was appointed to hold meetings with all leaders of national Muslim organizations as well as with Muslim leading figures. Furthermore, this commission was in charge of establishing relationship with Muslims all over the world. In addition to these efforts, the Commission for the Improvement of the Cooperation between ulama and the Government had agenda to visit the leading figures of the country, and all governmental institutions and departments. Meanwhile, the fatwa commission was urged to issue fatwa to support the success of the country's development and national defense. ${ }^{3}$

The themes discussed by the fatwa commission in this first year of establishment were far from studying various religious doctrines in Indonesia. Based on the result of the plenary meeting on 18 November 1975, the fatwa commission was given five themes which were drugs, holidays during the fasting month, setting off firecrackers, simple life and the government officials as pioneers in performing devotional activities. ${ }^{4}$

The duty to oversee the differing religious doctrines within the society was in the hands of the Commission for the Inter-religious Harmony. This commission was in charge of studying the doctrines of the differing sects in each of the five official religions, their organizational chartand operational methods. ${ }^{5}$ Accordingly, any fatwa or recommendation

\footnotetext{
2 See Dewan Pimpinan Majelis Ulama Indonesia, Majelis Ulama Indonesia 1976, Sekretariat Majelis Ulama Indonesia, Jakarta, 1976, pp. 48-49

3 Ibid., pp.84-85

${ }^{4}$ Ibid., p. 89

5 Dewan Pimpinan Majelis Ulama Indonesia, Majelis Ulama Indonesia 1976, p. 89
} 
on heretical doctrines, which were issued in this period, must be rooted from the result of the study conducted by this commission. ${ }^{6}$ However, the MUI did not discuss the Ahmadiyah doctrines yet.

In 1979 the Minister of Religious Affairs issued an instruction to the General Director of Muslim Guidance and Hajj Affairs, the Chairman of the Research and Development of the Ministry of Religious Affairs, the General Inspector and the chairmen of the Ministry of Religious Affairs in provincial level, that they improve their effort toward guiding, and overseeing the activities of the Islamic organizations and schools of thought which were contradictory to Islamic doctrines. In this regards, the Minister of Religious Affairs instructed these four leaders to improve their relationship and cooperation with the General Attorney, Department of Home Affairs, Badan Koordinasi Inteligen Negara (BAKIN) or the State Intelligent Coordinating Agency, local government, the Council of Indonesian Ulama (MUI), and all Islamic institutions in order to improve their guidance to those Islamic organizations and schools of thought. Furthermore, the instruction stated that the intended guidance must be in line with Islamic doctrines and legislations. ${ }^{7}$ It is clear that the establishment of the instruction of the minister of religious affairs, who was also the General Chairman of the Advisory board of the MUI at that time, influenced the emergence of the discussion on the Ahmadiyah doctrines in the second national conference of the MUI on 26 May - 1 June 1980.

However, it is difficult to uncover the background of the fatwa issuance since

${ }^{6}$ There was only one fatwa issued on heretical doctrine before the MUI issued the fatwa on the Ahmadiyah doctrine. The intended fatwa was addressed to the Jamaah Muslimin Hizbulaab which was issued in 1978.

${ }^{7}$ See the instruction of the Minister of Religious Affairs no.8/1979 on guiding and overseeing Islamic organizations and schools of thought which are contradicting Islamic doctrines, Mimbar Ulama no.36, 1980, pp. 62-63 information available surrounding it is rare. The only existing information was given by the fatwa commission which enlisted the Ahmadiyah case as one of its agenda in the second national conference in $1980 .{ }^{8}$ It denoted that the Ahmadiyah case was intended to be discussed in the meeting and that the case was considered crucial by the national MUI.

According to K.H. Ma'ruf Amin, the present Chairman of the Fatwa Commission of the national MUI, this first fatwa on Ahmadiyah was issued after the council was denounced by the society concerning this denomination. ${ }^{10}$ However, the name of the mustafti was not mentioned in the fatwa.

The fatwa was signed by three most authoritative people in the national MUI. They were Hamka, the General Chairman of the leadership board, ${ }^{11}$ Drs. H. Kafrawi, the secretary and Alamsjah Ratu Prawiranegara, the Chairman of the Advisory Board who was also the Minister of religious affairs at the time. This fatwa took the form of governmental decree which contained preamble and dictum. The preamble consisted of three points which I call "considering," "listening" and "observing" sections. Meanwhile, the dictum covered the substance of the fatwa.

In this fatwa, the "considering section" mentioned the Qur'an and The traditions of the Prophet. However, neither the specific verse of the Qur'an nor the Prophetic traditions were used as reference. The second section of the preamble, the "listening section" enlisted President Suharto speech, the introductory remarks given by Hamka as the General Chairman of the Leadership Board of the MUI and the speech given by the

\footnotetext{
${ }^{8}$ Anonymous, "Materi-Materiyang akan dibicarakan dalam Musyawarah Nasional II Majelis Ulama", Mimbar Ulama V/No.40 Mei/Juni 1980, p. 24

${ }^{9}$ There is a possibility for the provincial MUI to raise another issue which is not enlisted.

10 Aris Mustafa et.al, Ahmadiyah Keyakinan yang digugat, p. 144

${ }^{11}$ Hamka was reelected as the General Chairman of the Leadership Board of the MUI in the second national conference in 1980.
} 
Chairman of the Fatwa Commission who was K.H. Syukri Ghazali. ${ }^{12}$ In his speech Hamka stated that "in regards to religious cases the MUI depends on the Fatwa Commission. It is agreed that the uncertain (khilafiah) cases will not be discussed. Moreover, issuing a fatwa on Islamic law should cover all propositions and the opinions of all Islamic schools." ${ }^{\text {"13 }}$ Yet the fatwa on Ahmadiyah, as mentioned above did not mention any rationale or background of issuance. The last section of the preamble, the "observing section" mentioned the report of the fatwa commission as well as ideas and opinions of the participant of the conference. However, these two important items were not available. ${ }^{14}$

The dictum of the fatwa listed two points. The first point mentioned that, based on the data and facts found from the nine books on Ahmadiyah, the MUI declared that the Jamaah Ahmadiyah was a non-Islam group, heretical and deviant. The second point stated that in order to deal with the problem the MUI needed to get in touch with the government. This fatwa had no appendices giving additional explanation of the dictum. Therefore, it left one with an unclear argumentation on the nine intended books and their contents. Yet, none of the editions from 1980 to 1981 of the official magazine of the MUI, Mimbar ulama, discussed this fatwa. The Ahmadiyah continuously ask about the intended books and their heretical contents, to the present

${ }^{12}$ Unfortunately I cannot get the copies of the speeches of President Suharto and the chairman of the fatwa commission

${ }^{13}$ See, Prof.Dr. Hamka, 'MUNAS II Majelis Ulama se-Indonesia,' Mimbar Ulama, V/No.40 May/June 1980 , p. 7

${ }^{14}$ Sometimes the MUI omits the detail of any fatwa's arguments since many ulama were usually asked to present papers on the topics being deliberated. Detailed arguments and references are given in these papers, but not retained in the texts of the fatwas as issued. This entails that one needs to join the meeting in order to know the complete rationale behind the issuance of fatwa. Alternately, copies of the data on the conference provide the important information related to the fatwa. Nadirsyah Hosen, "Behind the Scene; Fatwas Majelis Ulama Indonesia,” p. 161 day.

The second point of the dictum, which states the need to cooperate with the government regarding the Ahmadiyah case, explained that the MUI did not have the right to ban certain denominations. Rather it is in the hands of the Pengawas Aliran Kepercayaan Masyarakat (PAKEM) or the Overseer of the People's Belief. ${ }^{15}$ This institution consisted of the Ministry of Religious Affairs, Ministry of Home Affair and the General Attorney. This interdepartmental institution is more powerful than the MUI since its main duty is

"To maintain 'stability and order', and this includes, inter alia, 'monitoring mystical beliefs movement that can be dangerous to people and the state, preventing the misuse and/or insult to religion'. Moreover, this body can investigate religious books, brochures, tracts, and materials produced in Indonesia or imported from foreign countries. Additionally, it has unlimited power to judge which religious and/or mystical beliefs is deviant and deviating and thus conceived as 'dangerous' to the people." 16

In fact, according to K.H. Ma'ruf Amin, there were nine Ahmadiyah branches closed after the fatwa was issued. ${ }^{17}$ However, the MUI has no such power to close these branches. Rather, they were closed after the General Attorney issued a decree on the Ahmadiyah Qadian Doctrine in October 1980.18

15 This institution was firstly established by the Ministry of Religious Affairs in 1954. But in 1960 the institution was taken under the ministry of justice and the general attorney. See Trisno S. Sutanto, The Challenges of Religious Freedom- An Indonesian Experience. pp. 3-4. Unpublished paper presented at the $56^{\text {th }}$ General Assembly of EKUMINDO, $14^{\text {th }}-16^{\text {th }}$ September 2006, Stuttgart, Germany. The online article can be read through the following link http://ec.europa. eu/external_relations/indonesia/eu_indonesia_day/ speeches/21_t_sutanto_chalenge_religious_freedom. pdf.

${ }^{16}$ Ibid., p. 4

17 Aris Mustafa et.al., Ahmadiyah keyakinan yang digugat, pp.145-146

${ }^{18}$ The issued decree is probably the decision of the PAKEM. However, it did not mention the ban on 
However, in the view of the Saudi government closing those Ahmadiyah branches would not stop the dissemination of the Ahmadiyah teachings. Therefore, the Saudi government through its embassy and the Attaché of Religious Affairs sent letters mentioning the decrees of the Muslim's World League, the Organization of Islamic Conference, and the International Council of Mosque on the Ahmadiyah Qadiyan heresy. The letters were aimed at reminding the government of Indonesia as an active member of the Muslim's World League to support its decree. In these letters, the Saudi government encouraged the Ministry of Religious Affairs to ban the Ahmadiyah (Qadian) and to explain its heresy to religious people in Indonesia. ${ }^{19}$ However, this intervention seemed to be ignored since the government did not voice any decree to strengthen the decree of the General Attorney on the Ahmadiyah doctrines.

Rather, the Indonesian government moves in regards to the Ahmadiyah case seemed to be ambiguous. In the one hand, the Minister of Religious Affairs signed the fatwa as a symbol of the government's agreement to the fatwa. On the other hand, he did not ban the arrival of the Vice-Khalifah of the Ahmadiyah on June 1981. Moreover, the Chairman of the local MUI of Tasikmalaya regency attended the meeting by the local Ahmadiyah at that time. $^{20}$

\section{The Recommendation on the Ahmadiyah Qadian in 1984}

Before the recommendation on the banning of the Ahmadiyah doctrines was issued in 1984, the District Attorney of

Ahmadiyah. Rather it mentions that the Ahmadiyah belief in Mirza's prophecy as contradicting the belief of the Indonesian Muslim

${ }^{19}$ The letter sent by the Saudi Arabia embassy in $6^{\text {th }}$ May 1981, while the attaché sent its letter a week after. However the content of the two letters is absolutely the same. See M. Amin Djamalludin, Abmadiyah Menodai Islam. pp. 138-145

20 Aris Mustafa et.al. Ahmadiyah keyakinan yang digugat pp. 91-91
West Lombok issued a decree in 1983 on the banning of the denomination. It was the Minister of Religious Affairs, Munawir Sjadzali, who brought the discussion on the banning on Ahmadiyah doctrine in the national working meeting in 1984. He encouraged the MUI to issue recommendations both on the Ahmadiyah and Shiite. He also presented a speech before the meeting was held, the preparatory meeting of the plenary meeting of the MUI, in which he explained about the Ahmadiyah. Regarding the Ahmadiyah case he emphasized banning only the Ahmadiyah Qadian since the Ahmadiyah Lahore doctrines does not contradict "Islamic faith". ${ }^{21}$ In the end, the recommendation on the Ahmadiyah was more or less influenced by the Minister's speech.

This recommendation was issued in one long decree, together with a fatwa on adoption, recommendations on taking benefit from the inherited land, performing Hajj and Shiite. It was signed by the General Chairman of the MUI, K.H. Syukri Ghazali and the General Secretary Qadir Basalamah. ${ }^{22}$ Compared to the fatwa in 1980, this recommendation gave more precise explanation on the MUI's view on the Ahmadiyah doctrines. The recommendation mentioned the decree of the Ministry of Justice on the status of the Ahmadiyah Qadian as a corporation. Furthermore, it stated that the Ahmadiyah teachings had evoked social unrest and disintegration, thus endangering the social stability and the security of the country. The social unrest, according to the recommendation, was a result of the dissimilarity of the Ahmadiyah doctrines from the Sunni Muslims'. In this case, the dissimilar doctrines are the belief on the death of Isa, the Prophecy and the divine revelation received by Mirza Ghulam

\footnotetext{
${ }^{21}$ See Departemen Penerangan RI, 10 Tahun Majelis Ulama Indonesia (26 Juli 1975 - 26 Juli 1985), pp. 112115

22 The complete text of this decree was published in Mimbar Ulama no. 81/1984, pp. 24-36. Besides, the above fatwa and recommendations were published in the compilation book of fatwa and also the official website separately.
} 
Ahmad, the founder of Ahmadiyah. Up to now, these doctrines are still being contested in and outside Indonesia. The disintegration, as in the recommendation, is in performing devotional activities such as in performing prayers. The Ahmadi people are not allowed to pray with a non-Ahmadi imam, otherwise, they need to redo the prayer. Besides, the Ahmadi people are not allowed to marry non-Ahmadi Muslim unless the non Ahmadi would like to pronounce the Ahmadi oath. Regarding this marriage affair, it is stated that the prohibition is aimed at creating a harmonious family where both husband and wife share the same vision. The Ahmadi people are obliged to pay a sum of money, chandah, to the Caliph. This obligation may not be fulfilled if either the husband or wife is not an Ahmadi; otherwise, he or she will lose the membership. ${ }^{23}$

Since the above problems may endanger the social stability and the security of the country, the MUI recommended that the local MUIs throughout Indonesia should explain the heresy of the Ahmadiyah doctrines and those who became members of this denomination to return to the "true Islam". In addition, the recommendation was ended with the call for increasing vigilance toward the Ahmadiyah doctrine.

This recommendation was followed by the issuance of circular letter by the General Director of Muslims Guidance and the Hajj Affairs, who was Qadir Basalamah, which was based on the recommendation of the MUI in 1984. This circular letter mentioned two points; the first point stated that the Ahmadiyah Qadian was considered a deviant group since it acknowledged its founder as a prophet; the second point which was based on the first, mentioned that in order not to evoke social unrest and irritate the society's religious harmony, the Ahmadiyah should not disseminate its doctrine outside of its community. ${ }^{24}$ In the same year, 1984, the

\footnotetext{
23 Aris Mustafa et.al., Ahmadiyah keyakinan yang digugat, pp. 129-130

${ }^{24}$ The content of this circular letter is quoted in the LPPI letter to the Supreme Court; see M. Amin
}

General Attorney stated that the Ahmadiyah doctrine was non-Islamic doctrine and that all its publications were banned and that its status as a corporation would be reviewed. ${ }^{25}$

In 1985 a non-governmental organization namely Lembaga Penelitian dan Pengkeajian Islam (LPPI) or the Institute of Research and Study on Islam was officially legalized. This institution was led by M. Amin Djamaluddin ${ }^{26}$ who holds the position up to the present day. He was the one who actively disseminated the result of his study on the Ahmadiyah book, the Tadzkirah. Based on his study, the Tadrkirab is a compilation of the verses of the Holy Koran which are mixed here and there. Additionally, before becoming the member of the MUI, Amin in the name of LPPI actively summoned the local resident of Parung ${ }^{27}$ to urge the local government on the status of the Ahmadiyah headquarters there. ${ }^{28}$ Besides he also sent letters to the Supreme Court in June 1994 and to the General Attorney in June 1996 on the banning of the Ahmadiyah nationally. ${ }^{29}$

These letters seemed to be influential to the PAKEM since it issued a decree on the

Djamaludin, Ahmadiyah dan Pembajakan Al-Qur'an, p. 135. See also recommendation of the central PAKEM on the ban on the Ahmadiyah in M. Amin Djamaluddin, Ahmadiyah Menodai Islam, pp. 118-119

${ }^{25}$ This decree was followed by the District Attorneys of Sidenreng Rappang in 1986, Tarakan in 1989, Jambi and North Sumatra in 1994. M. Amin Djamaluddin, Abmadiyah dan Pembajakan Al-Qur'an, pp. 90-93

${ }_{26}$ The LPPI, the institution led by Djamaluddin, enlisted as one of the members of the research team for the Ahmadiyah case. This team was found in 1990. See M. Amin Djamaluddin, Abmadiyah dan Pembajakan al-Qur'an, pp. 145-146. Djamaluddin has become the member of the commission of research in the MUI since 2000. However, I cannot reach any data mentioning the exact year of the LPPI or Amin enrollment to the MUI.

${ }^{27}$ It is the headquarters of the Ahmadiyah Qadian. It is located in West Java.

${ }^{28}$ See copies of letters to the local government urging to ban the Ahmadiyah conference in 1989. M. Amin Djamaluddin, Abmadiyah Menodai Islam, pp.127136 and pp.179-190

${ }^{29}$ The complete text of this letter can be read in M. Amin Djamaluddin, Abmadiyah dan Pembajakan AlQur'an, pp. 126-137 
banning of both Ahmadiyah Qadian and Lahore in 31 July 1996. However, according to Amin Djamaluddin, the government postponed the issuance of the decree since it was close to the forthcoming general election in 1997. Nevertheless, the reformation wave in that year made the decree ignored. ${ }^{30} \mathrm{Up}$ to the present, the decree remains unpublished.

\section{Fatwa on the Banning of the Two Differing Doctrines of Ahmadiyah in 2005}

The Ahmadiyah case re-emerged in 2000 when the Ahmadiyah held its annual meeting. In this meeting, which was intended to commemorate the $75^{\text {th }}$ years of the establishment of the Ahmadiyah Qadian in Indonesia, the committee cooperated with Dawam Rahardjo and his institution International Forum on Islamic Studies. They invited the fourth Caliph, Mirza Tahir Ahmad, to attend this meeting. Besides, with the help of Dawam Rahardjo, the Caliph managed to meet the President at the time, Gus Dur and the Chairman of the People's Consultative Council (Majelis Permusyawaratan Rakyat), Amin Rais. Rahardjo, then, stated that the meeting between the Caliph and these two figures was a sign that Indonesian Muslims could accept the Ahmadiyah's existence and that the MUI's fatwa was no longer valid. ${ }^{31}$ In response to this statement, the MUI pronounced campaign against heretical doctrines in its conference in 2000.

Additionally, in 2002 LPPI sponsored a seminar held in Istiqlal mosque, ${ }^{32}$ entitled "Ahmadiyah, its heresy and danger". The seminar was attended by the boards of the national and regional MUI, as well as ulama of the national Islamic organizations. It was reported that the seminar stimulated a number of people to attack the Ahmadiyah

\footnotetext{
${ }^{30}$ Misbah and Lovine, 'Mirza Lebih Parah dari Musailamah,' Sabili, no.3/2000, p. 36

${ }^{31}$ Misbah et.al. 'Menggugat Kesesatan Ahmadiyah,' Sabili, no.3/2000, p. 28

${ }^{32}$ The great mosque situated in Jakarta. The office of the national MUI is also in this mosque
}

headquarters in East Lombok. ${ }^{33}$ As a matter of fact, the attack was committed after a seminar on religion discussing the heretical sects in Indonesia including the Ahmadiyah. The seminar was held by the district MUI in which M. Amin Djamaluddin was invited to present the result of his study on the Ahmadiyah doctrines. ${ }^{34}$ Thus the destruction must have been stimulated by what he presented in the seminar.

Following the aforementioned seminar in 2002, the MUI held the fourth Muslims congress in April 2005 and resulted a decision mentioning that

"Aliran sesat" (heretical sects) should be a special priority having precedence over other major social problems such as corruption, bribery, adultery, abortion, pornography, porno-action, narcotics, gambling, alcohol, intellectual copyright, criminality, destruction of the environment, violence and enmity. ${ }^{35}$

This decision was enacted by the seventh national conference of the MUI in July 2005.

As a matter of fact, there were many denominations which were considered to be deviant. But it was only the Ahmadiyah doctrines which were discussed in the seventh national conference. The reason for issuing the case was probably the absence of the government policy on these denominations. Besides, there was continuous discussion on the Ahmadiyah doctrines among the society, so the case was discussed by the PAKEM. It held coordination meeting twice. The first meeting listed three religious denominations

${ }^{33}$ Komisi Hak Asasi Manusia (KOMNASHAM) or the Indonesian Commission for Human Right received a complaint regarding this matter and sent a letter of clarification to LPPI. See correspondence between KOMNASHAM and LPPI in M. Amin Djamaluddin, Ahmadiyah Menodai Islam, pp. 218-226

${ }^{34}$ See M. Amin Djamaluddin, Abmadiyah Menodai Islam, pp. 224-225 and also Aris Mustafa et.al. Abmadiyah Keyakinan yang digugat p. 31

${ }^{35}$ John Olle, "The Campaign against "Heresy"'- state and Society in Negotiation in Indonesia.' p. 2. Paper presented in the $16^{\text {th }}$ biennial conference of the Asian Studies Association of Australian in Wollongong 2629 June 2006 
as the topics for discussion, including the Ahmadiyah. In this first meeting, ${ }^{36}$ held on 18 January 2005, the national MUI sent two representatives to attend the meeting; they were Dr Utang Ranuwijaya and M. Amin Djamaluddin. The meeting was attended by representatives of the General Attorney, Police Headquarters, the Army Force Headquarters, the Department of Home Affairs, the Department of Foreign Affairs, the Department of Religious Affairs, the State Intelligence Agency (Badan Inteligen Nasiona), and the Department of Culture and Tourism. In this meeting, Dr. Utang Ranuwijaya explained the Ahmadiyah case reported by the provincial and the district MUI. These local MUIs demanded the banning of the Ahmadiyah since there had been many clashes between the Ahmadi and the non-Ahmadi. M. Amin Djamaluddin explained the doctrines of the Ahmadiyah, differing from those of the majority of Muslims in Indonesia as well as speaking of his personal experience of being interviewed by the Chairman of the National Commission for Human Rights. Besides, he showed the letters between LPPI and the Ahmadiyah. Eventually, all representatives in this meeting agreed upon banning the Ahmadiyah. However, the representatives of the Ministry of Religious Affairs suggested that the ban done locally since there was protest from the International Commission for Human Right. ${ }^{37}$ In the end the committee decided to ban both the Ahmadiyah Qadian

\footnotetext{
${ }^{36}$ This meeting was a continuation of the previous meeting in September 2004 which did not reach any decision whether to ban the Ahmadiyah locally or nationally. See M. Amin Djamaluddin, Abmadiyah Menodai Islam p. 104

${ }^{37}$ This information is gained from Djamaluddin's note while attending the coordination meeting. There was no additional explanation on the content the International commission for Human right protest and when it was issued. However, in this meeting the representatives of the Ministry of Foreign Affairs stated that many Indonesian embassies were often protested regarding the Ahmadiyah case. But the intended embassies and the protesters were not mentioned. M. Amin Djamaluddin, Abmadiyah Menodai Islam, pp. 104-110
}

and Ahmadiyah Lahore in Indonesia.

Subsequently the chairman of the meeting, the representative of the General Attorney, appointed the representatives of the Ministry of Religious Affairs, the Ministry of Home Affairs, the Police Headquarters, MUI and the General Attorney to make a draft of Presidential Decree on the banning of the Ahmadiyah, both Qadian and Lahore, in all part of Indonesia. ${ }^{38}$ Eventually, the meeting for making the draft was held on 12 May 2005.

Although the PAKEM had issued the draft into a recommendation, the government did not take any action. Rather, the Ahmadiyah got the license to hold an annual conference or Jalsah Salanah from both Provincial Police Department of West Java and the Head of the Regional Police in Bogor.

This approval encouraged LPPI to send a letter to these two institutions to revoke the license. Besides, LPPI also establish Posko Pembubaran Ahmadiyah secara Nasional or Post for Dismissing the Ahmadiyah Nationally. ${ }^{39}$ It follows from the above explanation that $\mathrm{M}$. Amin Djamaluddin, through his institutionLPPI is the one who continuously spreads the accusation on the Ahmadiyah heresy. Additionally, his status as a member of the national $\mathrm{MUI}^{40}$ enabled him to influence the special team of the fatwa commission to list the Ahmadiyah case in the seventh national conference in July 2005.

In short, the absence of the government policy on the Ahmadiyah, the continuous discussion on this denomination and the result of the coordination meeting of the PAKEM have made the MUI launch the Ahmadiyah case as an important issue in its seventh

${ }^{38}$ The intended draft was a recommendation for the President to issue a Presidential decree. M. Amin Djamaluddin, Ahmadiyah Menodai Islam, p. 110

${ }^{39}$ M. Amin Djamaluddin, Abmadiyah Menodai Islam, pp.194-196

${ }^{40} \mathrm{He}$ is enlisted as a member of the research commission of the national MUI in 2005-2010. See http://www.mui.or.id/mui_in/komisi_mui. php?id $=22$ 
national conference. Nevertheless, this latest fatwa on Ahmadiyah did not mention the result of the PAKEM or any District Attorneys decree on the Ahmadiyah. Rather, the fatwa which was aimed at strengthening the previous fatwa issued in 1980 was supported by the decision of the Organization of Islamic Conference on the deviating doctrines of the Ahmadiyah Qadian and the Ahmadiyah Lahore. ${ }^{41}$ However, echoing the result of the meeting of PAKEM, the MUI considered both Ahmadiyah Qadian and Ahmadiyah Lahore were sectarians.

The same as the previous fatwa in 1980, this recent fatwa does not mention the name of the Mustafti. Besides, the fatwa has no appendices that the reason for issuing the fatwa remains unclear. Regarding this matter the MUI then published a book which explained all the issued fatwas in the seventh national conference including the Ahmadiyah in 2007. The book explains that the fatwa was issued after many questions proposed by the society through various forums, letters and emails. ${ }^{42}$ These questions were selected by the Tim Materi (Material Team) of the fatwa commission for the national conference. The team, which was led by K.H. Ma'ruf Amin, consisted of 15 people and most of them were from the Fatwa Commission. The eleven selected cases were then discussed by the team. Then, they made the fatwa drafts of each of the case in two days. The drafts were then submitted to the Fatwa Commission to be reviewed. Next, the drafts were submitted to the plenary national conference board to be legalized. ${ }^{43}$

\footnotetext{
${ }^{41}$ See www.mui.or.id for the fatwa on the Ahmadiyah doctrine in 2005

${ }^{42}$ Majelis Ulama Indonesia, Fatwa Munas VII Majelis Ulama Indonesia: perlindungan hak kekayaan intelektual, perdukunan (kahanab) dan peramalan ('irafah), do'a bersama, perkawinan beda agama, kewarisan beda agama, kriteria maslahat, pluralisme, liberalisme, dan sekularisme agama, pencabutan bak milik pribadi untuk kepentingan umum, wanita menjadi imam shalat, bukuman mati dalam tindake pidana tertentu, aliran Ahmadiah, disertai lampiran penjelasan fatwa, 2005, pp.136-137

43 Aris Mustafa et.al. Ahmadiyah Keyakinan yang Digugat. pp.149-151
}

However, before issuing the fatwa the MUI had undergone a study on the Ahmadiyah by tracing its history of establishment, assessing books written by Mirza Ghulam Ahmad and the leading figures of the two differing schools of the Ahmadiyah as well as their doctrines through their publications. Besides, the MUI studied the Qur'an, the Prophetic traditions, the ulama consensus and their opinions and also the world ulama's fatwas on the Ahmadiyah. ${ }^{44}$ The intended study must have been done before the case being brought to the national conference because the special committee was given two days to make the draft of the fatwa. Since the fatwa is aimed at strengthening the previous fatwa in the second national conference, the intended study may also mean to rely on the research on the Ahmadiyah which was conducted in 1980.

Similar to the previous fatwa, this latest fatwa contains of two parts. The first part is the preamble consisting of the "considering section," "bearing in mind section," and "observing section". The second part mentions the dictum.

In the first section of the preamble, "considering section," the fatwa listed four points mentioning the backgrounds of issuing the fatwa. The background consisted of (i) the continuous dissemination of the Ahmadiyah doctrine though there is a fatwa which forbids it ${ }^{45}$ (ii) the effort to develop the Ahmadiyah doctrines has evoked social unrest, (iii) the demand for the affirmation of the MUI's fatwa on the Ahmadiyah doctrines in relation to the emergence of various opinions and reactions within the society, and (iv) the need to strengthen the fatwa on Ahmadiyah doctrine, in order to fulfill the demand to purify Islamic belief.

Different from the previous fatwa and

\footnotetext{
${ }^{44}$ Majelis Ulama Indonesia. Fatwa Munas VII Majelis Ulama Indonesia pp.136-137

${ }^{45}$ Both the MUI's recommendation issued in 1984 and the decree of the ministry of religious affairs issued in 1984 on the banning on the dissemination of the Ahmadiyah doctrine are not mentioned here.
} 
recommendation, in this latest fatwa the MUI emphasized the Ahmadi belief in Mirza as a prophet. It is stated in the second section of the preamble, "bearing in mind section," which mentions particular verses of the Qur'an such as chapter 33 verse 40 on the Prophet Muhammad prophecy, chapter 6 verse 153 on the "right path of Islam" and chapter 5 verse 105 on maintaining faith. This section also enlisted two Prophetic traditions; the first tradition which was narrated by Bukhari mentioned that there will not be any prophet after the Prophet Muhammad; and the other tradition which was narrated by Tirmidhi having the same content with different phrasing. ${ }^{46}$

The last section of the preamble, the "observing section," mentions the decree of the Organization of Islamic Conference on Ahmadiyah Qadian and Ahmadiyah Lahore as deviants in 1985, the fatwa issued on Ahmadiyah in 1980 and the opinion of the fatwa commission in the seventh national conference in $2005 .{ }^{47}$ The MUI referred to the decree of the Organization of Islamic Conference since Indonesia is a member of this organization. However, this reference gives lead to a number of interpretations. First, the MUI acknowledges the authority of this international organization, and second, the MUI needs to underpin its decision by referring to a more wide-scale organization. This decree mentioned the following statement

"Truthfully, what is claimed by Mirza Ghulam Ahmad on his prophecy, the doctrines he carried and revelations descended on him are strict deviancy against the definite Islamic doctrines that the Prophet Muhammad is the last messenger and Prophet; and that there would be no more revelations descended on anyone after this. The belief disseminated by Mirza Ghulam Ahmad

\footnotetext{
${ }^{46}$ See the translation of the cited verses and the Prophet traditions in the fatwa text in the MUI official website www.mui.or.id.

47 The opinion of the fatwa commission in this conference is not provided.
}

has made him and his followers become apostates, deviating from Islam. The Ahmadiyah Qadian and the Ahmadiyah Lahore are the same, although the later (the Ahmadiyah lahore) believes that Mirza Ghulam Ahmad is the shadow and the continuation of the Prophet Muhammad." ${ }^{48}$

In fact, this quotation is the explicit supporting reason for banning the Ahmadiyah, both Qodian and Lahore. By contrast, the two points in this section do not relate to the dictum of fatwa directly, especially since the fatwa in 1980 is addressed to Ahmadiyah Qodian only, and the opinions of the fatwa commission are not available.

In the above preamble, the dictum of the fatwa which is in the last section listed three points. The first point reaffirmed the first issued fatwa in 1980 stating that the Ahmadiyah doctrines are heretical, deviant and deviant and that Muslims who follow these doctrines are apostates. The second point stated that those who became members of these denominations should return to "the right path" of Islam which is in line with the Qur'an and the Prophetic traditions. The last point states that the government should ban the doctrines in all over Indonesia and ban their organizations and close their offices.

\section{The Struggle for Banning the Ahmadiyah in Indonesia after the Fatwa in 2005}

After issuing this fatwa, the MUI held a sequence of meetings. These were the Forum of the Muslims Community in $16^{\text {th }}$ August 2005, the Islamic Brotherhood Forum of the MUI in $27^{\text {th }}$ August 2005, a meeting with the $8^{\text {th }}$ commission of the Indonesian Legislative Assembly (DPR) in $31^{\text {st }}$ August 2005, a meeting with leaders of Islamic organizations and the Head of the Indonesian Police in $6^{\text {th }}$ September 2005, and the Islamic brotherhood forum of the MUI in $10^{\text {th }}$ September 2005, on

${ }^{48}$ It is translated from the Indonesian translation of the Arabic text of the OIC decree quoted in the fatwa. 
the status of Ahmadiyah in Indonesia. ${ }^{49}$ In order to strengthen the recent fatwa the MUI sent a letter to the Minister of Home Affairs, the Minister of Religious Affairs, the General Attorney and the Head of the Indonesian Police Department. The letter mentioned that the Ahmadiyah in Indonesia has evoked social unrest and conflict amongst society. Besides their doctrines have stigmatized Islamic doctrines and evoked enmity which in turn will potentially create instability. Therefore, the MUI encouraged the addressee of this letter to ban the Ahmadiyah, to revoke their status as official organizations, to strictly obey their leaders and preachers and also to save and guide the Ahmadiyah followers to return to the "right path of Islam" as it is stated in the Qur'an, the traditions of the Prophet and as it is acknowledged by the ulama. ${ }^{50}$

Having read the above fatwa and the letter, it is clearly proved that the MUI exhibited its right to judge which denomination is holding the right path and which did not. This right is supported by the present President who in his speech during the opening ceremony of the seventh national conference of the MUI stated that he would support the MUI decision regarding Islamic belief. ${ }^{51}$ Besides, the MUI also get the support from the national ulama after gathering them in sequences of meeting. Additionally, the ulama support can be seen in their agreement to sign the letter of recommendation addressed to the President

${ }^{49}$ Letter sent by the national MUI to the Minister of Home Affair, the Minister of Religious Affair, the General Attorney and the Head of the Indonesian Police Department dated in $10^{\text {th }}$ September 2005. M. Amin Djamaluddin, Ahmadiyah Menodai Islam, pp. 162163

${ }^{50}$ The copy of the letter together with the list of signatures can be read in M. Amin Djamaluddin, Abmadiyah Menodai Islam, pp. 162-170

51 The President put forward the following statement "Kami ingin meletakean MUI untuk berperan secara sentral yang menyangkut akidah ke-Islaman, dengan demikian akan jelas bedanya mana-mana yang itu merupakan atau wilayah pemerintahan kenegaraan, dan mana-mana yang pemerintah atau negara sepatutnya mendengarkan fatwa dari MUI dan para Ulama." http://www.presidensby.info/ index.php/pidato/2005/07/26/370.html on the banning on the Ahmadiyah. Rather, it gained greater confidence to intervene the making of the state policy after getting the support from the President as well as the national ulama.

In fact the MUI is not an institution which holds the right to ban certain denominations. As mentioned previously, it is the PAKEM, of which the MUI is one of the members, which holds the authority to do so. The support of the President may belittle the power of the PAKEM, which has the authority to judge certain denominations whether religious or mystical, to be deviant. However, the PAKEM is not the most powerful body able to ban any religious or mystical groups; it is the President who holds the final decision on banning such group. This is the reason why the MUI sent the above mentioned letter to him to consider. This letter mentioned all fatwas issued by the World ulama, the fatwas of Indonesian ulama, as well as the decrees of both the General and the District Attorneys on the "heretical" doctrine of the Ahmadiyah..$^{52}$ However, after the letter was sent, neither the PAKEM nor the President issued any decree on the Ahmadiyah doctrines. On the contrary, this latest fatwa evoked lots of critiques.

In response to the criticism, the MUI later on issued ten points of heresy. These points were formulated in the national working meeting held from $4^{\text {th }}$ to $6^{\text {th }}$ November 2007. It was attended by all members of the national MUI as well as provincial and regency levels. In this meeting, President Susilo Bambang Yudhoyono, while delivering his speech, stated that he would support the MUI's decision. ${ }^{53}$

\footnotetext{
${ }^{52}$ The copy of the letter together with the list of signature can be read in M. Amin Djamluddin, Ahmadiyah Menodai Islam, pp. 172-184

${ }^{53}$ The President in the national working meeting in 2007 put forward the following statement "Ada 13 poin yang ditulis MUI. Yang pertama lakukan langkah-langkah sangat tegas dan tepat terhadap aliran dan paham sesat. Saya dukung, mari kita jalankan bersama-sama," http:/ / www.antara.co.id/arc/2007/11/5/presiden-dukunglangkah-tegas-terhadap-aliran-sesat. The President was mistakenly referring to the 10 criteria of heresy mentioned previously and stated that the criteria
} 
In line with the President, the Head of the Police Department stated that he would arrest the leader of the deviant denomination and its followers. ${ }^{54}$ However, these points of heresy also received a lot of criticism since it might lead the society to commit anarchy. The ten points cover those sects which;

a. deny the principle of faith (rukun iman) and the principle of Islam (rukun Islam) ${ }^{55}$

b. believe or follow certain belief which is not in line with Koran and the Prophet tradition

c. believe in the revelation after the Holy Koran

d. deny the authenticity and the truth of the content of the Holy Koran

e. interprettheHolyKoranwithoutdepending on the principle of the interpretation of the Holy Koran

f. deny the position of the Prophet tradition as the source of Islamic doctrine

g. underestimate the messengers and the prophets

h. deny the Prophet Muhammad as the last messenger and the last prophet

i. change the principles of the ibadab which determined by Islamic law

j. consider other Muslims as apostate without argument ${ }^{56}$

Regarding the above points of heresy, the spokesperson of the MUI, Yunahar Ilyas, stated that not everyone can determine whether a certain denomination as a deviant. Furthermore, he said that a sect can be consisted of 13 points.

${ }^{54}$ See Rumadi et al. "Sepuluh Pedoman Penyesatan, Masyarakat Bertindak Sendiri."Monthly Report on Religious Issues, fourth edition, November 2007 www. gusdur.net

${ }^{55}$ Rukun Iman covers the believe in God, His Angels, His Holy Books, His Messengers, The Doomsday and The Divine Decree or Qadha and Qadar. Rukun Islam is the five basic principles of Islam. It covers pronouncing syahadat, performing five times prayers, fasting in the Holy Month (Ramadhan), paying for Zakat (charity) and Performing Pilgrimage to Mecca.

56 http://www.antara.co.id/arc/2007/11/6/muitetapkan-10-kriteria-aliran-sesat considered heretic if one of the ten points of heresy was found in its doctrine. However, according to the secretary of the MUI, Ichwan Sam, these points cannot be used by any person to judge one particular sect as heretical. Additionally, he said that there were certain mechanisms and procedures which must be followed and subsequently studied. Furthermore, one needed to bear in mind that issuing a fatwa was not that easy. The MUI's statute says before judging one particular sect as heretic, research on it must be conducted. Data, information, evidence and witnesses for the concept, rationale, and the sect's activities must be gathered and studied by the appointed commission. Then, this commission will invite the leader of the sect and the witnesses on the data, information, and the gathered evidence. Finally, the result is given to the Leadership Board of the national MUI. Furthermore, if necessary this board may assign the fatwa commission to discuss and issue a fatwa. In the fatwa on the heretical sects, there is a point mentioning that the MUI refers everything to the apparatus and warning the society not to commit anarchy. ${ }^{57}$ In short, these two leading figures of the MUI tried to convince that the council had studied one particular religious denomination through certain accurate procedures before denouncing it as deviant.

Based on the above criteria, at least, there are three points of heresy found in the Ahmadiyah doctrines. These three points are (i) believe in the revelation after the Qur'an, (ii) denial the Prophet Muhammad as the last messenger and the last prophet, (iii) considering other Muslims as apostate.

The first point deals with a book, namely Tadrkirab which comprises the compilation of revelations descended upon Mirza during his life. Mirza wrote the verses by himself without any assistance or witness. ${ }^{58}$ These revelations were written separately in at least four books that are al-Barriyah, Haqiqatul Wabyi, Zamimah

\footnotetext{
57 http://www.antara.co.id/arc/2007/11/6/muitetapkan-10-kriteria-aliran-sesat/

${ }^{58}$ M. Amin Djamaludin, Abmadiyah dan Pembajakan Al-Qur'an, p. 70
} 
Haqiqatul Wabyi, Khutbah Ilhamiyab. ${ }^{59}$ These verses, then, were compiled together with Mirza's dreams, articles, daily notes, spiritual experience and the confession of the eye witnesses about the revelation and Mirza's life. According to M. Amin Djamaluddin's study, most of the verses acknowledged as divine revelations to Mirza were combinations of many verses found in the Qur'an. Moreover, some of the verses were combination between verses on the Qur'an with Mirza's word either in Arabic, Urdu or Persian language. ${ }^{60}$ The book compiled under the instruction of the second Caliph, Mirza Bashiruddin Mahmud Ahmad, Mirza's son ${ }^{61}$ is not considered as a holy book for the Ahmadi. ${ }^{62}$ Nevertheless, they acknowledge that Mirza received divine revelations from God which are compiled in the book. ${ }^{63}$ It is based on this book that the Ahmadiyah teachings are considered heretic.

The second point relates to the belief in Mirza as a prophet who continued the duty of Muhammad. Mirza himself declared that he was a Messenger of God and never revoked it to his death. His confession is written in many of his books such as Eik Ghalti ka Iralah, Daafi'ul Bala, and Haqiqatul Wabyi. Besides, he also wrote this declaration in newspapers namely Badr, published on 5 March 1908, and Akbbar-I Aam published on 26 May 1908, the day when he died. ${ }^{64}$ His confession is

${ }^{59}$ Hasan Suhaib and Tufail Muhammad, Abmadiyah Minoritas Non-Muslim, Yayasan Ishlah Al-Ummah, 1986, p. 7

${ }^{60}$ See M. Amin Djamaluddin, Abmadiyah dan Pembajakan Al-Qur'an, p.iii and see also Aris Mustafa et.al., Ahmadiyah Keyakinan yang Digugat, p. 5

${ }^{61}$ M. A. Suryawan, Bukan Sekedar Hitam PutihKontroversi Pemahaman Ahmadiyah. Az-Zahra Publishing. Tangerang, 2006, pp. 64-65. See also in Aris Mustafa et.al., Ahmadiyah Keyakinan yang digugat, p. 63

${ }^{62}$ See Aris Mustafa et.al. Abmadiyah Keyakinan yang Digugat. p. 63

${ }^{63}$ See M. A. Suryawan, Bukan Sekedar Hitam PutihKontroversi Pemahaman Abmadiyah, pp. 66-69. In regards to Tadzkirah, the Rois Tabligh or the Head of Religious Meeting considered it as Hadith Qudsi or the Prophet traditions which were divinely revealed. Misbah et.al., 'Menggugat Kesesatan Ahmadiyah,' Sabili no.3/2000, p. 31

${ }^{64}$ Hasan Suhaib and Tufail Muhammad, Abmadiyah acknowledged by the Ahmadiyah Qadian followers. However, the belief in Mirza as a prophet after Muhammad is in contrast to the MUI's belief in the Prophet Muhammad as the last prophet. These two different opinions come from different interpretation on certain word on one of the verses on the Qur'an bearing a word Khotamul anbiya'. The Ahmadi people interpret the phrase Khotamul anbiya' to mean that the Prophet Muhammad is the main or the most important prophet ${ }^{65}$, so this interpretation does not avoid the possibility of emerging a new prophet. Furthermore, the Ahmadi people also stated that the Prophet Muhammad is the last prophet who was given the responsibility to disseminate syariah while Mirza did not do it for he was just sent to strengthen Muslim's faith. ${ }^{66}$ Ahmadi people also believe that Mirza is the Promised Messiah, as he admitted himself, who continued the Prophet Muhammad's duty. ${ }^{67} \mathrm{On}$ the contrary, the MUI interprets khotamul anbiya' as the seal of the prophet, meaning that there will not be any prophet sent to people on earth after the Prophet Muhammad. This interpretation is also supported by the Prophetic tradition in which He stated la nabiyya ba'di or there will be no other prophets coming after me. In contrast to The Ahmadiyah Qadian belief, the Ahmadiyah Lahore merely considers him as a reformist. However, the one they referred to, as discussed above, admitted himself as a prophet.

The last point related to condemning others as deviant. Related to this condemnation, it was the non-Ahmadi ulama who issued fatwas on the Ahmadis' heresy. Because of these fatwas the Ahmadis are not allowed to perform prayer behind a non-Ahmadi. ${ }^{68}$ Moreover, Mirza also forbid his follower to

\footnotetext{
Minoritas Non-Muslim. pp. 4-6

${ }^{65}$ See Munawar Ahmad, 'Faith and Violence.' www. serve.com

${ }^{66}$ See Aris Mustafa et.al. Ahmadiyah Keyakinan yang digugat. p. 61.

${ }^{67}$ Ibid., p. 62

68 M. A. Suryawan, Bukan Sekedar Hitam Putih, pp.141-147
} 
marry their children with the non-Ahmadi. ${ }^{69}$ However, the second Caliph put forward the following statement "all Muslims who do not acknowledge the truth of al-Masib, although he/she has never heard his name, is an infidel and is an apostate. I admit this with all my faith." ${ }^{70} \mathrm{He}$ also issued another fatwa mentioning that one's Islam is illegal when he or she does not belief in Mirza Ghulam Ahmad. This fatwa was published in Bigham Shalab in 19 April $1933 .^{71}$ This means that the non-Ahmadi people are apostate.

Despite these three points, the fact that the MUI issued these two fatwas and a recommendation on the Ahmadiyah showed that the MUI paid a lot of concern to this denomination. It also entails that the MUI insisted the government ban the Ahmadiyah in Indonesia. Whether or not this demand is approved by the government can determine its position among Indonesian Muslims and intellectuals after the fall of Suharto. ${ }^{72}$

\section{Conclusion}

Although the MUI was free from the influence of the International Islamic organizations, the influence of the government in issuing the first fatwa on Ahmadiyah in 1980 and the recommendation in 1984 cannot be denied. The content of the first fatwa and the recommendation on the Ahmadiyah did not mention any reference to any decree on the same case. These two decrees show that the MUI is an organization which is independent. It derived its decree merely from its own perspective. The fact that Indonesia

\footnotetext{
${ }^{69}$ For more information on the Ahmadi view on Marriage see Aris Mustafa et.al., Ahmadiyah Keyakinan yang digugat, pp. 129-131

${ }^{70}$ Hasan Suhaib and Tufail Muhammad, Abmadiyah Minoritas Non-Muslim, p.7

${ }^{71}$ Misbah et.al., 'Menggugat Kesesatan Ahmadiyah,' Sabili no.3/2000, p.31

${ }^{72}$ In this case I agree with Gillespie who argues that the MUI is contesting its position among Indonesian Muslims and intellectuals after the fall of the late President Suharto. See Gillespie, Piers,. 'Current Issues in Indonesian Islam; Analysing the 2005 Council of Indonesian Ulama Fatwa no.\& Opposing Pluralism, Liberalism and Secularism,' p. 39
}

becomes a member of Muslim world, which issued a decree on the Ahmadiyah in 1974, did not encourage the MUI to issue the fatwa on this denomination in the first year of its establishment in 1975. Rather, the MUI issued the first fatwa on the Ahmadiyah in 1980 after the Minister of Religious Affairs asked the MUI to oversee religious organizations.

Additionally, in 1981, the Saudi government asked the Indonesian government to enact the decree of the Muslim World League and ban the Ahmadiyah in Indonesia. However, the government seemed to ignore it since there was no decree or fatwa issued by the government or the MUI on the denomination. The issuance of recommendation in 1984 was also a result of the influential speech by the Minister of Religious Affairs. From these two decrees, the role of the Minister of Religious Affairs, who was the General Chairman of the Advisory board, is very strong. It is of his advice that the MUI issue the fatwa and the recommendation. There was no protest or social moves recorded in accordance with the issuance of these two decrees of the MUI.

On the contrary, the MUI received no influence from the government before issuing the last fatwa; however, it acknowledged the influence from the Organization of Islamic Conference (OIC) since the last fatwa issued in 2005 mentioned the decree of this organization. This means the MUI needed an international organization's decree to support its fatwa. In other words, the MUI is no longer independent.

The first fatwa on the Ahmadiyah merely defines that the denomination is heretic. The recommendation mentions advices; first, to the ulama to explain the heretical teachings of the Ahmadiyah; second, for the Ahmadi to return to "the right path of Islam" and third, to all Muslims not to be influenced by the teaching of this denomination. It is only in the second fatwa that the MUI "obliges" the government to ban the dissemination of the Ahmadiyah teachings throughout Indonesia. In this case, we can see that the MUI is trying to redefine 
fatwa as a binding religious decree.

The last fatwa is the only edict which experiences oppositional reaction from the society; since it mentions the banning on the Ahmadiyah teaching. This reaction drives the MUI to issue the ten criteria of heresy. Through these criteria, the MUI demonstrates the meaning of the phrase "the right path of Islam." Therefore, any denomination which does not bear any of the above criteria is allowed to be address as "the right Islam." The criteria also defines that the MUI is the Indonesian religious authority which has the right to decide which teaching is right and which one is not. In accordance to the Ahmadiyah case, the MUI through the fatwas, recommendation and the published ten criteria of heresy convince all Indonesian Muslims that Ahmadiyah is deviating Islam.

\section{REFERENCES}

Anonymous, "Materi-Materi yang akan dibicarakan dalam Musyawarah Nasional II Majelis Ulama", Mimbar Ulama V/No.40 Mei/Juni 1980.

Anonymous, Instruksi Menteri Agama no.8/1979 tentang Pembinaan, Bimbingan dan Pengawasan terhadap Organisasi dan Aliran dalam Islam yang bertentangan dengan Ajaran Islam, Mimbar Ulama no.36. 1980.

Anonymous. Keputusan Rapat Kerja Nasional Majelis Ulama se-Indonesia, Mimbar Ulama no. 81. 1984.

Aris Mustafa et.al., Abmadiyah Keyakinan yang digugat, Pusat Data dan Analisa Tempo. 2005.

Departemen Penerangan RI, 10 Tahun Majelis Ulama Indonesia (26 Juli 1975 - 26 Juli 1985). 1985.

Dewan Pimpinan Majelis Ulama Indonesia, Majelis Ulama Indonesia 1976, Sekretariat Majelis Ulama Indonesia. 1976.

Gillespie, Piers, 'Current Issues in Indonesian Islam; Analysing the 2005 Council of Indonesian Ulama Fatwa no.\&
Opposing Pluralism, Liberalism and Secularism, Journal of Islamic Studies No. 18 Vol. 2. 2007.

Hasan Suhaib and Tufail Muhammad, Abmadiyah Minoritas Non-Muslim, Yayasan Ishlah Al-Ummah. 1986.

John Olle, 'The Campaign against "Heresy"state and Society in Negotiation in Indonesia.' p. 2. Paper presented in the $16^{\text {th }}$ biennial conference of the Asian Studies Association of Australian in Wollongong 26-29 June 2006.

Majelis Ulama Indonesia, Fatwa Munas VII Majelis Ulama Indonesia: perlindungan hak kekayaan intelektual, perdukunan (kahanab) dan peramalan (irafah), do'a bersama, perkawinan beda agama, kewwarisan beda agama, kriteria maslahat, pluralisme, liberalisme, dan sekularisme agama, pencabutan hak milik pribadi untuk. kepentingan umum, wanita menjadi imam shalat, bukuman mati dalam tindak pidana tertentu, aliran Abmadiah, disertai lampiran penjelasan fatwa. 2005.

Misbah and Lovine, 'Mirza Lebih Parah dari Musailamah,' Sabili, no.3/2000.

Misbah et.al., 'Menggugat Kesesatan Ahmadiyah,' Sabili no.3/2000.

M. Amin Djamaludin, Ahmadiyah dan Pembajakan Al-Qur'an. Lembaga Penelitian dan Pengkajian Islam. 2000.

M. Amin Djamalludin, Abmadiyah Menodai Islam. Lembaga Penelitian dan Pengkajian Islam. 2007.

M. A. Suryawan, Bukan Sekedar Hitam PutibKontroversi Pemahaman Abmadiyah. AzZahra Publishing. 2006.

Munawar Ahmad, 'Faith and Violence.' www. serve.com

Nadirsyah Hosen, "Behind the Scene; Fatwas Majelis Ulama Indonesia (1975-1998)," Journal of Islamic Studies. No. 15 Vol. 2. 2004.

Prof.Dr. Hamka, 'MUNAS II Majelis Ulama se-Indonesia,' Mimbar Ulama, V/No.40 May/June 1980. 
70 | De Jure, Jurnal Syariah dan Hukum, Volume 2 Nomor 1, Juni 2010, hlm. 55-70

Prof. Dr. Hamka, "Pidato Ketua Umum Majelis Ulama Indonesia Empat Tahun," Mimbar Ulama 1984

Rumadi et al. "Sepulub Pedoman Penyesatan, Masyarakat Bertindak Sendiri." Monthly Report on Religious Issues," fourth edition, November 2007. www.gusdur. net

Trisno S. Sutanto, The Challenges of Religious Freedom-An Indonesian Experience.pp. 3-4. Unpublished paper presented at the $56^{\text {th }}$ General Assembly of EKUMINDO, $14^{\text {th }}-16^{\text {th }}$ September 2006, Stuttgart, Germany.

http://www.antara.co.id/arc/2007/11/6/ mui-tetapkan-10-kriteria-aliran-sesat

http:/ / www.discoverthenetworks.org/ groupProfile.asp?grpid $=7347$.

http://www.mui.or.id/mui_in/komisi_mui. php?id $=22$

http://www.presidensby.info/index.php/ pidato/2005/07/26/370.html 